\title{
Experimental comparison of autograft and DBM Flex (Grafton) for spinal lumbar fusion in rabbits
}

\author{
Tavşanlarda spinal lomber füzyon için otogreft ve DBM Flex'in (Grafton) deneysel karşılaştırması \\ Cem Demirel ${ }^{1}$, Dursun Türköz ${ }^{2}$, Tuncal Yılmaz ${ }^{2}$
}

\begin{abstract}
Aim: The choice of graft materials used for spinal fusion possesses a great importance due to their crucial roles in bone remodelling. Although autogenous bone grafts are the "gold standard" for spinal fusion surgeries, they can cause various complications. Aim of this study was to compare the efficacy of demineralized bone matrix (DBM) and autograft in lumbar spinal fusion in a rabbit model of spinal lumbar fusion (SLF).

Methods: Twenty New Zealand rabbits were randomly divided into two groups and underwent SLF by using either iliac crest autologous bone graft (Autograft, n=10) or DBM Flex (Grafton, n=10). Eight-weeks after surgery, animals were sacrificed and spinal fusion was evaluated by computerized tomography (CT), manual palpation, macroscopic analyses, and histological assessments.

Results: CT results revealed that autograft led to significantly higher fusion scores than DBM Flex ( $\mathrm{p}=0.0004)$. Mobility was significantly lower in autograft group $(\mathrm{p}=0.0007)$. Significantly lower bone formation scores were observed in DBM Flex group compared to autograft group ( $<<0.0001)$. Histology of spine in the autograft group was significantly better than DBM Flex group $(\mathrm{p}=0.0002)$.

Conclusion: Autograft was superior than DBM flex in SLF and these results indicate that autograft will continue to be the "gold standard" in SLF in the future.

Keywords: Autograft, DBM Flex, Demineralized bone matrix, Grafton, Spinal fusion surgery
\end{abstract}

\section{Öz}

Amaç: Spinal füzyon için kullanılan greft materyallerinin seçimi, kemiğin yeniden şekillenmesindeki öneml rolleri nedeniyle büyük önem taşımaktadır. Otojen kemik greftleri spinal füzyon ameliyatlarında "altın standart" olmasına rağmen çeşitli komplikasyonlara neden olabilir. Bu çalışmanın amacı, tavşan spinal lomber füzyon (SLF) modelinde demineralize kemik matrisi ve otogreftin etkinliğini karşılaştırmaktı.

Yöntem: Yirmi Yeni Zelanda tavşanı rastgele iki gruba ayrıldı ve iliak krest otolog kemik grefti (Autogreft, $\mathrm{n}=10$ ) veya DBM Flex (Grafton, $\mathrm{n}=10$ ) kullanılarak SLF uygulandı. Ameliyattan sekiz hafta sonra hayvanlar sakrifiye edildi ve spinal füzyon bilgisayarlı tomografi (BT), manuel palpasyon, makroskopik analizler ve histolojik değerlendirmelerle değerlendirildi.

Bulgular: BT sonuçları, otogreftin DBM Flex'ten anlamlı derecede daha yüksek füzyon skorları sağladığını ortaya koydu $(\mathrm{p}=0,0004)$. Hareketlilik otogreft grubunda anlamlı olarak daha düşüktü $(\mathrm{p}=0,0007)$. DBM Flex grubunda, otogreft grubuna kıyasla anlamlı derecede daha düşük kemik oluşum skorları gözlendi $(p<0,0001)$. Otogreft grubundaki omurga histolojisi, DBM Flex grubuna göre anlamlı olarak daha iyiydi $(\mathrm{p}=0,0002)$.

Sonuç: Otogreft, SLF'de DBM flex'ten daha üstün bulunmuştur ve bu sonuçlar da otogreftin gelecekte de SLF'de "altın standart" olarak kabul edileceğini göstermektedir.

Anahtar kelimeler: Otogreft, DBM Flex, Demineralize kemik matrisi, Grafton, Spinal füzyon cerrahisi
${ }^{1}$ Samsun University, Faculty of Medicine, Department of Neurosurgery, Samsun, Turkey.

${ }^{2}$ University of Health Sciences, Samsun Education and Research Hospital, Department of Neurosurgery, Samsun, Turkey.

\section{CD: 0000-0002-6084-4075}

DT: 0000-0003-3599-0895

TY: 0000-0002-5055-8913

Ethics Committee Approval: This study was approved by the Animal Experiments Local Ethics Committee (Ondokuz Mayis University Animal Experiments Ethics Committee; Approval date: 24/08/2009; Approval No: HADYEK/68).

Etik Kurul Onayı: Bu çalışma Hayvan Deneyleri Yerel Etik Kurulu tarafindan onaylanmıştır (Ondokuz Mayıs Üniversitesi Hayvan Deneyleri Etik Kurulu; Onay tarihi: 24/08/2009; Onay No: HADYEK/68).).

Conflict of Interest: No conflict of interest was declared by the authors.

Çıkar Çatışması: Yazar çıkar çatışması bildirmemiștir.

Financial Disclosure: The authors declared that this case has received no financial support.

Finansal Destek: Yazarlar bu çalışma için finansal destek almadıklarını beyan etmişlerdir.

Geliş Tarihi / Received: 08.07.2021

Kabul Tarihi / Accepted: 02.12.2021

Yayın Tarihi / Published: 09.12.2021

Sorumlu yazar / Corresponding author:

Cem Demirel

Adres/Address: Samsun University, Faculty of Medicine, Department of Neurosurgery. Samsun Saglik Uygulama ve Arastirma Merkezi, İlkadim, Samsun, Turkey.

e-mail: drcemdemirel@hotmail.com

Tel/Phone: +90362311 1500

Copyright (C) ACEM 


\section{Introduction}

Functional spinal unit (FSU) is defined as the smallest segment exhibiting biomechanical characteristics of entire spine and consists of two adjacent vertebrae, intravertebral disc, facet (zygapophyseal) joints, joint capsules and supporting ligamentous structures [1]. Spinal instability is the development of pain and neurological deficits that prevent daily activities due to the inability of the spine to maintain its integrity, to prevent abnormal displacements, to prevent damage to the spinal cord and nerve roots under physiological loads on the spine as a result of acute or chronic insufficiency in FSU [2].

Spinal fusion surgeries with or without instrumentation have been widely performed to treat the patients with spinal pathologies. There are numerous factors such as surgical methods, graft materials, postoperative rehabilitation [3] and comorbidities [4] may affect the success of the fusion surgery. Since the fusion does not occur in a short time after fusion surgery is performed and systemic complications due to longterm immobilization may develop, use of spinal instrumentation with fusion surgery has been brought to the agenda [5, 6]. On the other hand, instrumentation without fusion is not a long-term solution for fixation as in a long-term, loosening will occur, therefore, long-term stabilization will only be possible with osseous fusion [7, 8]. The choice of the graft materials used for the spinal fusion possesses a great importance as they play important roles in bone remodelling and therefore, an optimal graft should have the properties as osteoconductive, osteoinductive and osteogenic [9].

Autogenous bone grafts, the grafts that have been harvested from another anatomical location of the patient and transplanted to another location, have been considered as the "gold standard" for spinal fusion surgeries [10]. Although the success rate of them with strong fusion capacity without the risk of rejection, they have some disadvantages such as the variations in graft quality due to the metabolism and age of the patients [11] and risk of blood loss and pain at the site of harvest [12], and autograft harvest-associated morbidity was estimated to be observed in 10-39\% of the patients [13].

The alternatives materials for autografts including allograft, demineralized bone matrix (DBM), various synthetic materials such as calcium sulphates and calcium phosphates growth factors and cell- or platelet-based therapies have become alternatives for the autografts $[9,14]$. DBM is the bone that has been treated with acid to demineralize the bone while keeping the organic matrix and growth factors intact [15]. Its osteoconductive and osteoinductive capacities are limited [15, 16], however, it has no osteogenic capacity [15]. On the other hand, DBM does not lead to any immunological reaction in the host because of acid treatment during the preparation of the material [17]. Moreover, DBM has been shown to induce spine fusion successfully in the experimental animals [18, 19].

In this study, we aimed to compare the efficacies of DMB flex (Grafton) and autograft on a model of posterior spinal incision of New Zealand white rabbits.

\section{Material and methods}

\section{Experimental Groups and Animal Husbandry}

This study was approved by the local Animal Experiments Local Ethics Committee. Skeletally mature $20 \mathrm{New}$ Zealand White Rabbits (3 - $4 \mathrm{~kg}$ body weight) with both sexes were randomly divided into two groups as DMB flex $(\mathrm{n}=10)$ and iliac crest autograft $(n=10)$ groups. All animals were housed under controlled temperatures $\left(21 \pm 1^{\circ} \mathrm{C}\right)$ and controlled lighting conditions (12-h light/ dark cycle) in individual cages with ad libitum access to food and water.

\section{Surgical Procedures}

One hour previous to the experiments, each animal was coded with a number and received $20 \mathrm{mg} / \mathrm{kg}$ cefazolin as antibiotic prophylaxis. For surgery, animals were anesthetized by intraperitoneal administration of $3 \mathrm{mg} / \mathrm{kg}$ xylazine (Rompun ${ }^{\circledR}$ Bayer) and $40 \mathrm{mg} / \mathrm{kg}$ ketamine hydrochloride (Ketalar ${ }^{\circledR}$ - Parke Davis). After anaesthesia was achieved, animals were positioned in prone position on operating table, surgical site was shaved, and skin was cleaned with $10 \%$ povidone iodine solution.

In DBM flex group of animals, a five cm midline incision was carefully performed, and subcutaneous layers were dissected. Fascia was opened from sinister to the midline in line with the L4-L6 vertebrae. Lamina of L5 and facet joints at L4/5 and L5/6 were decorticated by using a high-speed burr with 3 $\mathrm{mm}$ ball-end. DBM flex (Grafton) with an approximate size of $20 \times 15 \mathrm{~mm}$ was grafted between the facet joints, and closure of fascia and subcutaneous tissues was achieved by using 3/0 vicryl sutures and skin closure was achieved by using $3 / 0$ silk suture following homeostasis. The incisions were cleaned with $10 \%$ povidone iodine solution and animals were placed in their individual cages.

In iliac crest autograft group of animals, a five $\mathrm{cm}$ midline incision was carefully performed. After lumbar fascia was dissected bilaterally, the soft tissues on the iliac crest was dissected carefully. The bone graft with a size of $20 \times 15 \times 4 \mathrm{~mm}$ was harvested by bone rongeur. Homeostasis of the iliac crests was achieved by bone wax application. The autograft bone material was decorticated by using a high-speed burr with $3 \mathrm{~mm}$ ball-end. Lamina of L5 and facet joints at L4/5 and L5/6 were bilaterally decorticated by using a high-speed burr with $3 \mathrm{~mm}$ ball-end. Surgical region was cleaned, homeostasis was achieved, and iliac crest graft was placed. The closure of fascia and subcutaneous tissues was achieved by using $3 / 0$ vicryl sutures and skin closure was achieved by using 3/0 silk suture following homeostasis. The incisions were cleaned with $10 \%$ povidone iodine solution and animals were placed in their individual cages.

\section{Postoperative Care}

After the surgery, $2 \mathrm{mg} / \mathrm{kg}$ meperidine for analgesia and $20 \mathrm{mg} / \mathrm{kg}$ cefazolin sodium for antibacterial activity were administered intraperitoneally to each animal. General condition, neurological findings, mobility and infection findings in the animals were closely monitored and recorded for a week. Neurological deficits and alteration vital signs were not observed in any of the subjects in the early postoperative period. Animals were fed with standard diet and followed for eight weeks. Eight weeks later the animals were sacrificed by high dose lysthenon administration.

\section{Computerized Tomography}

After sacrification, animals were taken to the radiology department and surgical region was scanned by thin slice computerized tomography (CT) and reconstructed into 3D images. Images were evaluated in terms of fusion and bone 
formation. The fusion was scored as follows: net fusion $=2$, likely fusion $=1$, no fusion $=0$.

\section{Bone Formation}

Manual Palpation and Macroscopic Evaluation of

After CT scans, the spinal region between L7 and L2 including the objective lumbar spine (L4-L6) was dissected and surrounding soft tissue was removed. Fusion was assessed by manual palpation as previously described [20, 21]. The motion was assessed by a blinded examiner, and in case of that no motion was detected in the segments (L4/5 and L5/L6), the implanted graft was assessed as fused and scored as 2. If there was a motion in the segments assessed, the implanted graft was assessed as not fused and scored as 1 .

Bone formation was also evaluated macroscopically and scored as follows: no new bone formation $=0$, minimal new bone formation $=1$, moderate new bone formation $=2$, obvious new bone formation $=3$.

\section{Histological Assessments}

The spinal segment that was dissected en bloc and fixed in $10 \%$ formalin solution for $24 \mathrm{~h}$ and dehydrated in ethanol solutions. After dehydration, harvested samples were decalcified in $10 \%$ nitric acid for seven days and embedded in paraffin. Longitudinal slices with five $\mu \mathrm{m}$ thickness were taken from the paraffin embedded samples and were stained with Hematoxylin and Eosin (H\&E) by using the standard protocol. The success of the fusion was evaluated by an experienced pathologist who were blinded to groups as previously described by Emery et al. [22].

\section{Statistical Analysis}

Statistical analyses were conducted by using the Statistical Package for the Social Sciences (SPSS) version 15.0 (IBM). Data are expressed as mean \pm standard deviation (SD). Normal distribution of the data was evaluated by Shapiro-Wilk normality test. Data with normal distribution was evaluated by independent Student's t-test while the data without normal distribution was evaluated by Mann-Whitney $U$ test. The associations between the variables were evaluated by Chi Square test. A p value lower than 0.05 was accepted as statistically significant.).

\section{Results}

\section{Computerized Tomography}

CT results revealed that one animal had likely fusion and the rest of the animal did not have any fusion in DBM Flex group (Figure 1A). On the other hand, six animals received autograft had net fusion, three animals had likely fusion and one animal had no fusion (Figure 1B). Mean fusion scores was significantly higher in the autograft group compared to DBM Flex group (Figure 1C; $p=0.0004$ ).

\section{Bone Formation}

\section{Manual Palpation and Macroscopic Evaluation of}

Examination by manual palpation showed that in iliac crest autograft group, no motion was observed in any of the animals while in DBM Flex group, motion was detected in eight of the animals $(\mathrm{p}=0.0007)$.

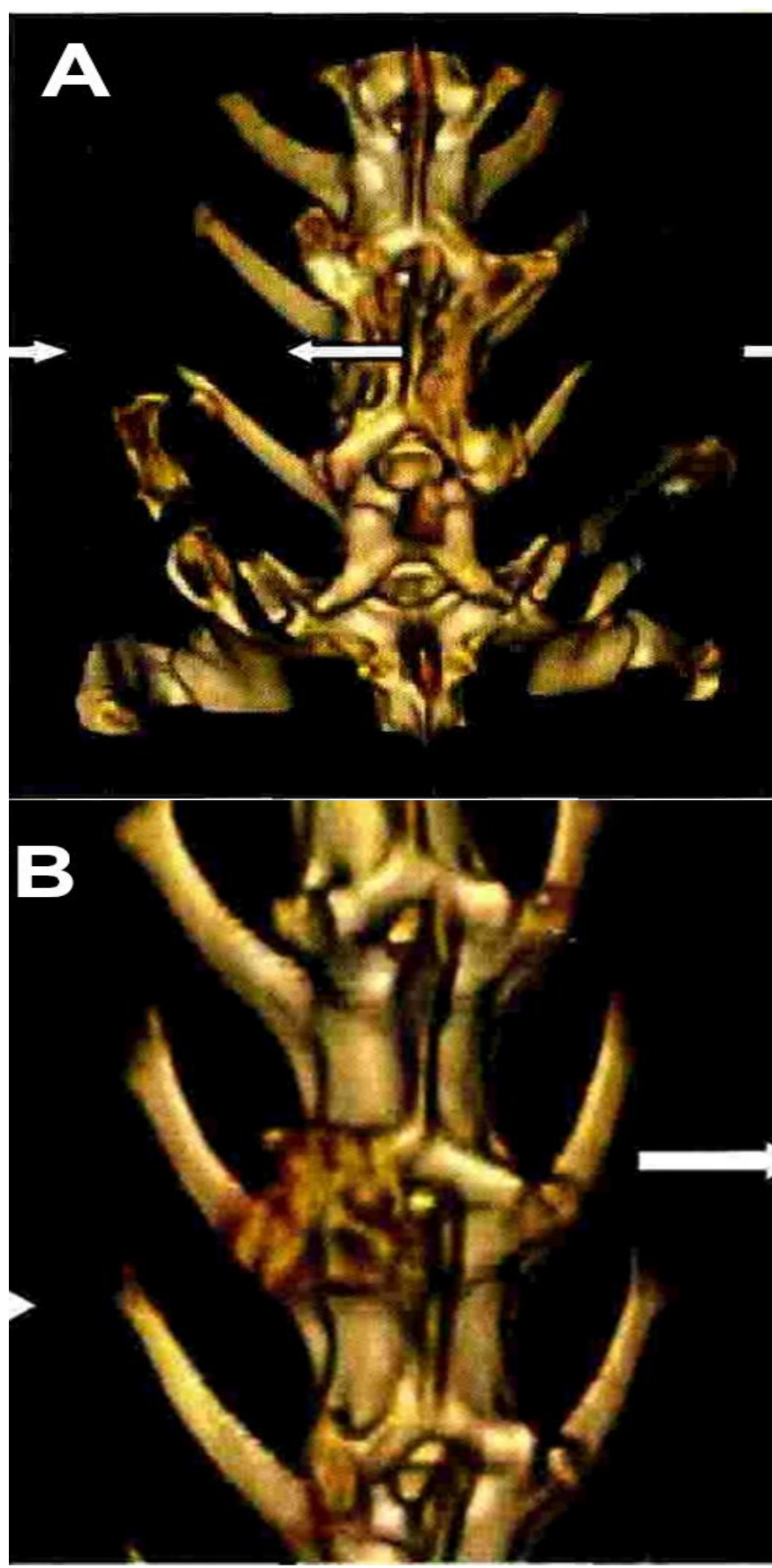

C

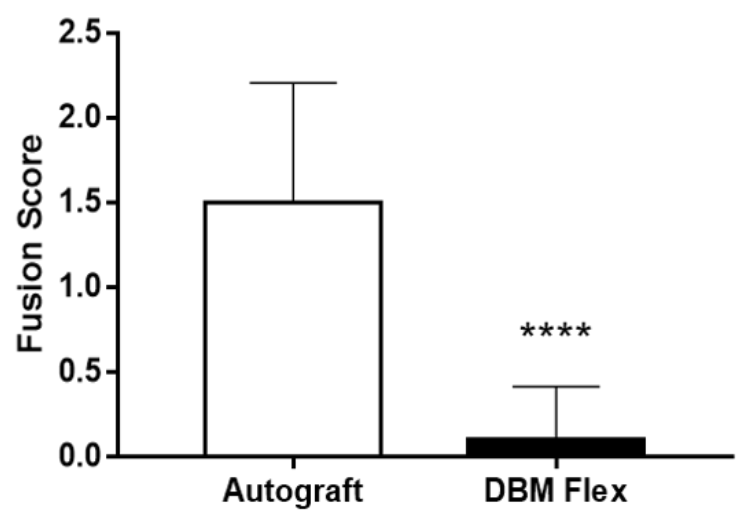

Figure 1. Representative 3D reconstruction of CT images of (A) Autograft, (B) DBM Flex groups. Arrows indicate the grafting region and bone formation four weeks after the grafting. (C) Fusion score of both groups. (Statistical analyses: Mann-Whitney U test. $* * * \mathrm{p}=$ $0.0004)$. 
DBM Flex grafting led to no new bone formation in nine of the animals and minimal new bone formation in one animal in the macroscopic evaluation of the bone formation. However, in the autograft group, an obvious new bone formation was observed in nine animals and moderate new bone formation in one animal $(\mathrm{p}<0.0001)$.

\section{Histological Assessments}

DBM Flex group of animals exhibited significantly lower histopathological score $(1.20 \pm 1.40)$ compared to autograft group of animals $(3.50 \pm 2.07$; Figure $2 \mathrm{~A}-\mathrm{C} ; \mathrm{p}=$ 0.0002).
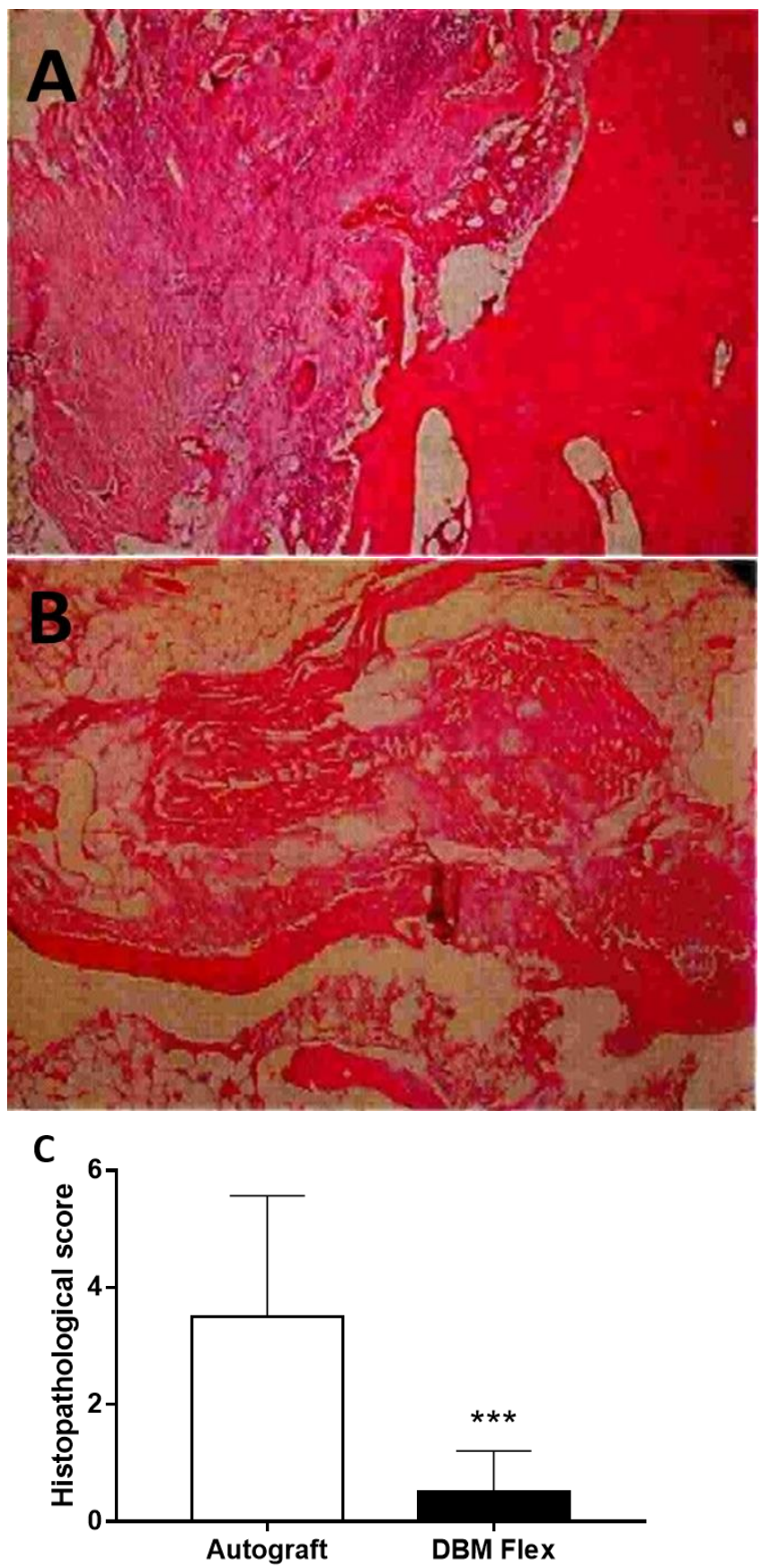

Figure 2. Representative histopathological images of (A) autograft group and (B) DBM Flex group. (C) Histopathological scores of both groups. (Statistical analyses: Mann-Whitney U test. $* * * p=0.0002$ ).

\section{Discussion}

Achieving satisfactory spinal fusion has been the most important issue in the surgery of spinal pathologies [14, 23, 24]. Today, although we can provide spinal stabilization in the early period by using complicated spinal instruments, the success in long term is achieved with the development of fusion. In this study, we compared the efficacy of autograft and DBM Flex (Grafton) in spinal fusion and found that autograft is superior than DBM Flex in spinal fusion.

The most commonly used substitute materials in spinal fusion are autograft and allograft bones [25] and autogenous bone graft has been implicated as the "gold standard" for spinal fusion grafting [10]. Iliac crest bone grafts are the most commonly used substitute in spinal fusion [26]. Although autografts have various advantages including promotion of extensive fusion with perfect histocompatibility, autograft harvest-associated morbidities can be observed in a significant part of the patients [13]. Therefore, use of different graft materials were required in spinal fusion surgeries.

DBM is a synthetic substitute that is particularly osteoinductive and is partially osteoconductive [23]. On the other hand, bone formation was indicated to be supported by DBM through osteoconductive mechanisms [19]. The results regarding the success achieved in spinal fusion by use of DBM are variable. A study conducted by Cook et al. on dogs revealed that either alone or together with allograft, DBM is not effective in formation of stable spinal fusion [27]. Helm et al., in their study indicated that DBM has an inhibitory role on spinal fusion in dogs [28]. In rabbits, although autograft was found to yield higher spinal fusion rates compared to allograft and allograft together with DBM, the difference between the groups were not significant [29]. However, several animal studies indicated that different forms of DBM act as a graft extender/enhancer and provide superior fusion rates than autograft only [19, 30]. Similar controversial results regarding the success after DBM grafting in spinal fusion surgery were also obtained by various clinical studies [31-37]. On the other hand, autograft alone was shown to induce bone formation to a higher extent than DBM alone in dogs [30].

Scoring was used in all three examinations, since spinal fusion has stages of inflammation, vascularization, osteoinduction, osteoconduction and remodeling. We observed that autograft yielded significantly higher lumbar spinal fusion than DBM Flex as revealed by the manual palpation and fusion score. Moreover, use of autograft for spinal fusion surgery led to a significantly better histology than DBM Flex grafting. This might be attributed to the extensive osteoinductive, osteoconductive and osteogenic properties of autografts [38-40].

In conclusion, our results suggest that autograft is superior than DBM Flex in spinal fusion. In our opinion, use of autograft in spinal fusion surgery will continue to be the "gold standard" for spinal fusion in the future. Further studies to find a suitable and efficient candidate substitute for autografts are required to avoid the complications that may arise due to autologous bone harvesting.

\section{Acknowledgement}

We would like to thank Prof. Murat Danacı for his kind and valuable helps in the evaluations of bone formation.

\section{References}

1. Iorio JA, Jakoi AM, Singla A. Biomechanics of Degenerative Spinal Disorders. Asian spine journal. 2016;10:377-84. 
2. Panjabi MM. Clinical spinal instability and low back pain. J Electromyogr Kinesiol. 2003;13:371-9. Christensen FB. Lumbar spinal fusion. Outcome in relation to surgical methods, choice of implant and postoperative rehabilitation. Acta Orthop Scand Suppl. 2004;75:2-43.

3. Mannion AF, Fekete TF, Porchet F, Haschtmann D, Jeszenszky $\mathrm{D}$, Kleinstuck FS. The influence of comorbidity on the risks and benefits of spine surgery for degenerative lumbar disorders. European spine journal : official publication of the European Spine Society, the European Spinal Deformity Society, and the European Section of the Cervical Spine Research Society. 2014;23 Suppl 1:S66-71.

4. Cheung JP, Luk KD. Complications of Anterior and Posterior Cervical Spine Surgery. Asian spine journal. 2016;10:385-400.

5. Reid PC, Morr S, Kaiser MG. State of the union: a review of lumbar fusion indications and techniques for degenerative spine disease. J Neurosurg Spine. 2019;31: 1-14.

6. Wang YS, Yin L, Bao H, Wang WD. Titanium mesh fusion device in the treatment of thoracolumbar burst fracture. Chin Med J (Engl). 2007;120:246-7.

7. Hanafy MN, Hanafy AM, Sheha AF, Gad SS. Evaluation of the short-term outcome of anterior approach surgery of the dorsal and lumbar spine. Menoufia Med J. 2014;27:413.

8. Buser Z, Brodke DS, Youssef JA, Rometsch E, Park JB, Yoon ST et al. Allograft Versus Demineralized Bone Matrix in Instrumented and Noninstrumented Lumbar Fusion: A Systematic Review. Global Spine J. 2018;8:396-412.

9. D'Souza M, Macdonald NA, Gendreau JL, Duddleston PJ, Feng AY, Ho AL. Graft Materials and Biologics for Spinal Interbody Fusion. Biomedicines. 2019;7:75.

10. Grabowski G, Robertson R. Bone allograft with mesenchymal stem cells: a critical review of the literature. Hard Tissue. 2013;2: 20.

11. Kurz LT, Garfin SR, Booth RE, Jr. Harvesting autogenous iliac bone grafts. A review of complications and techniques. Spine (Phila Pa 1976). 1989;14:1324-31.

12. Carlisle ER, Fischgrund JS (2009) Bone Graft and Fusion Enhancement. In: Errico TJ, Lonner BS, Moulton AW (eds) Surgical Management of Spinal Deformities. W.B. Saunders, Philadelphia, pp 433-48.

13. Vaccaro AR, Chiba K, Heller JG, Patel T, Thalgott JS, Truumees $\mathrm{E}$ et al. Bone grafting alternatives in spinal surgery. Spine J. 2002;2:206-15.

14. Tilkeridis K, Touzopoulos P, Ververidis A, Christodoulou S, Kazakos K, Drosos GI. Use of demineralized bone matrix in spinal fusion. World journal of orthopedics. 2014;5:30-7.

15. Salih E, Wang J, Mah J, Fluckiger R. Natural variation in the extent of phosphorylation of bone phosphoproteins as a function of in vivo new bone formation induced by demineralized bone matrix in soft tissue and bony environments. Biochem $\mathrm{J}$. 2002;364(Pt 2):465-74.

16. Tuli SM, Singh AD. The osteoninductive property of decalcified bone matrix. An experimental study. J Bone Joint Surg Br. 1978;60:116-23.

17. Morone MA, Boden SD. Experimental posterolateral lumbar spinal fusion with a demineralized bone matrix gel. Spine (Phila Pa 1976). 1998;23:159-67.

18. Martin GJ, Jr., Boden SD, Titus L, Scarborough NL. New formulations of demineralized bone matrix as a more effective graft alternative in experimental posterolateral lumbar spine arthrodesis. Spine (Phila Pa 1976). 1999;24:637-45.

19. Grauer JN, Bomback DA, Lugo R, Troiano NW, Patel TC, Friedlaender GE. Posterolateral lumbar fusions in athymic rats: characterization of a model. Spine J. 2004;4:281-6.

20. Miyazaki M, Zuk PA, Zou J, Yoon SH, Wei F, Morishita Y et al. Comparison of human mesenchymal stem cells derived from adipose tissue and bone marrow for ex vivo gene therapy in rat spinal fusion model. Spine (Phila Pa 1976). 2008;33:863-9.

21. Emery SE, Brazinski MS, Koka A, Bensusan JS, Stevenson S. The biological and biomechanical effects of irradiation on anterior spinal bone grafts in a canine model. J Bone Joint Surg Am. 1994;76:540-8.

22. Drosos GI, Kazakos KI, Kouzoumpasis P, Verettas DA. Safety and efficacy of commercially available demineralised bone matrix preparations: a critical review of clinical studies. Injury. 2007;38: S13-21.

23. Lee KJ, Roper JG, Wang JC. Demineralized bone matrix and spinal arthrodesis. Spine J. 2005;5(6 Suppl):217s-23s.
24. Gupta A, Kukkar N, Sharif K, Main BJ, Albers CE, El-Amin Iii SF. Bone graft substitutes for spine fusion: A brief review. World J Orthop. 2015;6:449-56.

25. Delawi D, Dhert WJ, Castelein RM, Verbout AJ, Oner FC. The incidence of donor site pain after bone graft harvesting from the posterior iliac crest may be overestimated: a study on spine fracture patients. Spine (Phila Pa 1976). 2007;32:1865-8.

26. Cook SD, Dalton JE, Prewett AB, Whitecloud TS, 3rd. In vivo evaluation of demineralized bone matrix as a bone graft substitute for posterior spinal fusion. Spine (Phila Pa 1976). 1995;20:87786.

27. Helm GA, Sheehan JM, Sheehan JP, Jane JA, Jr., diPierro CG, Simmons NE et al. Utilization of type I collagen gel, demineralized bone matrix, and bone morphogenetic protein- 2 to enhance autologous bone lumbar spinal fusion. J Neurosurg. 1997;86:93-100.

28. Urrutia J, Thumm N, Apablaza D, Pizarro F, Zylberberg A, Quezada F. Autograft versus allograft with or without demineralized bone matrix in posterolateral lumbar fusion in rabbits. Laboratory investigation. J Neurosurg Spine. 2008;9:84-9.

29. Frenkel SR, Moskovich R, Spivak J, Zhang ZH, Prewett AB. Demineralized bone matrix. Enhancement of spinal fusion. Spine (Phila Pa 1976). 1993;18:1634-9.

30. Thalgott JS, Giuffre JM, Fritts K, Timlin M, Klezl Z. Instrumented posterolateral lumbar fusion using coralline hydroxyapatite with or without demineralized bone matrix, as an adjunct to autologous bone. Spine J. 2001;1:131-7.

31. Cammisa FP, Jr., Lowery G, Garfin SR, Geisler FH, Klara PM, McGuire RA et al. Two-year fusion rate equivalency between Grafton DBM gel and autograft in posterolateral spine fusion: a prospective controlled trial employing a side-by-side comparison in the same patient. Spine (Phila Pa 1976). 2004;29:660-6.

32. Ungureanu G, Chitu A, Iancu I, Kakucs C, Maior T, Florian IS. Gender Differences in the Self-assessment of Quality of Life and Disability After Spinal Fusion for Chronic Low Back Pain at a Neurosurgical Center in Eastern Europe. Neurospine. 2018;15:261-8.

33. Navarro SM, Frankel WC, Haeberle HS, Ramkumar PN. Fixed and Variable Relationship Models to Define the Volume-Value Relationship in Spinal Fusion Surgery: A Macroeconomic Analysis Using Evidence-Based Thresholds. Neurospine. 2018;15:249-60.

34. Mayo BC, Haws BE, Bohl DD, Louie PK, Hijji FY, Narain AS et al. Postoperative Fever Evaluation Following Lumbar Fusion Procedures. Neurospine. 2018;15:154-62.

35. Fay LY, Chang CC, Chang HK, Tu TH, Tsai TY, Wu CL et al. A Hybrid Dynamic Stabilization and Fusion System in Multilevel Lumbar Spondylosis. Neurospine. 2018;15:231-41.

36. An HS, Simpson JM, Glover JM, Stephany J. Comparison between allograft plus demineralized bone matrix versus autograft in anterior cervical fusion. A prospective multicenter study. Spine (Phila Pa 1976). 1995;20:2211-6.

37. Keskin D, Gundogdu C, Atac AC. Experimental comparison of bovine-derived xenograft, xenograft-autologous bone marrow and autogenous bone graft for the treatment of bony defects in the rabbit ulna. Med Princ Pract. 2007;16:299-305.

38. Dimitriou R, Jones E, McGonagle D, Giannoudis PV. Bone regeneration: current concepts and future directions. BMC Med. 2011;9:66.

39. Brydone AS, Meek D, Maclaine S. Bone grafting, orthopaedic biomaterials, and the clinical need for bone engineering. Proc Inst Mech Eng H. 2010;224:1329-43. 